\title{
Significant Findings from a Water-Quality Study on Prairie Band Potawatomi Reservation, Northeastern Kansas, June 1996 through August 2006
}

By Heidi E. Mehl, Heather C. Ross Schmidt, and Larry M. Pope

Water-quality samples were collected from surface(stream-) and ground-water sites on and near the Prairie Band Potawatomi Reservation in northeastern Kansas (fig. 1) from June 1996 through August 2006 as part of a cooperative study between the U.S. Geological Survey (USGS) and the Prairie Band Potawatomi Nation (Schmidt and others, 2007). Surface- and ground-water quality were evaluated using applicable drinking-water standards to consider whether these resources can be used in the future to supply drinking water for the reservation. Presently (2007), drinking water on the reservation is purchased from Rural Water District \#3 in Jackson County (Sharon Bosse, Prairie Band Potawatomi Nation Department of Planning and Environmental Protection, oral commun., 2007). Results of water-quality analyses are summarized in the following sections. Water-quality activities for this study are documented in several reports (Trombley, 1999, 2001; Schmidt, 2004; Schmidt and others, 2007).

\section{Dissolved Solids and Major lons}

- Dissolved-solids concentrations typically were less than the $500-\mathrm{mg} / \mathrm{L}$ criteria established for drinking water. Generally, dissolved-solids concentrations in surface- and ground-water samples did not regularly exceed the Secondary Drinking-Water Regulation (SDWR) of $500 \mathrm{mg} / \mathrm{L}$ (milligrams per liter) set by the U.S. Environmental Protection Agency (2006), with the exception of one surface-water site and one ground-water site (LSC06 and MW03, fig. 1). The surface-water site is located downstream from a wastewater-treatment facility, and elevated dissolved-solids concentrations in water from well MW03 probably are the result of dissolution of sedimentary rocks.

- Sodium concentrations in surface- and ground-water-quality samples on the reservation frequently were equal to or greater than the U.S. Environmental Protection Agency (USEPA) 20-mg/L Drinking-Water Advisory (DWA) in finished drinking water for people who are on restricted sodium diets (500 milligrams per day) (U.S. Environmental Protection Agency, 2006).

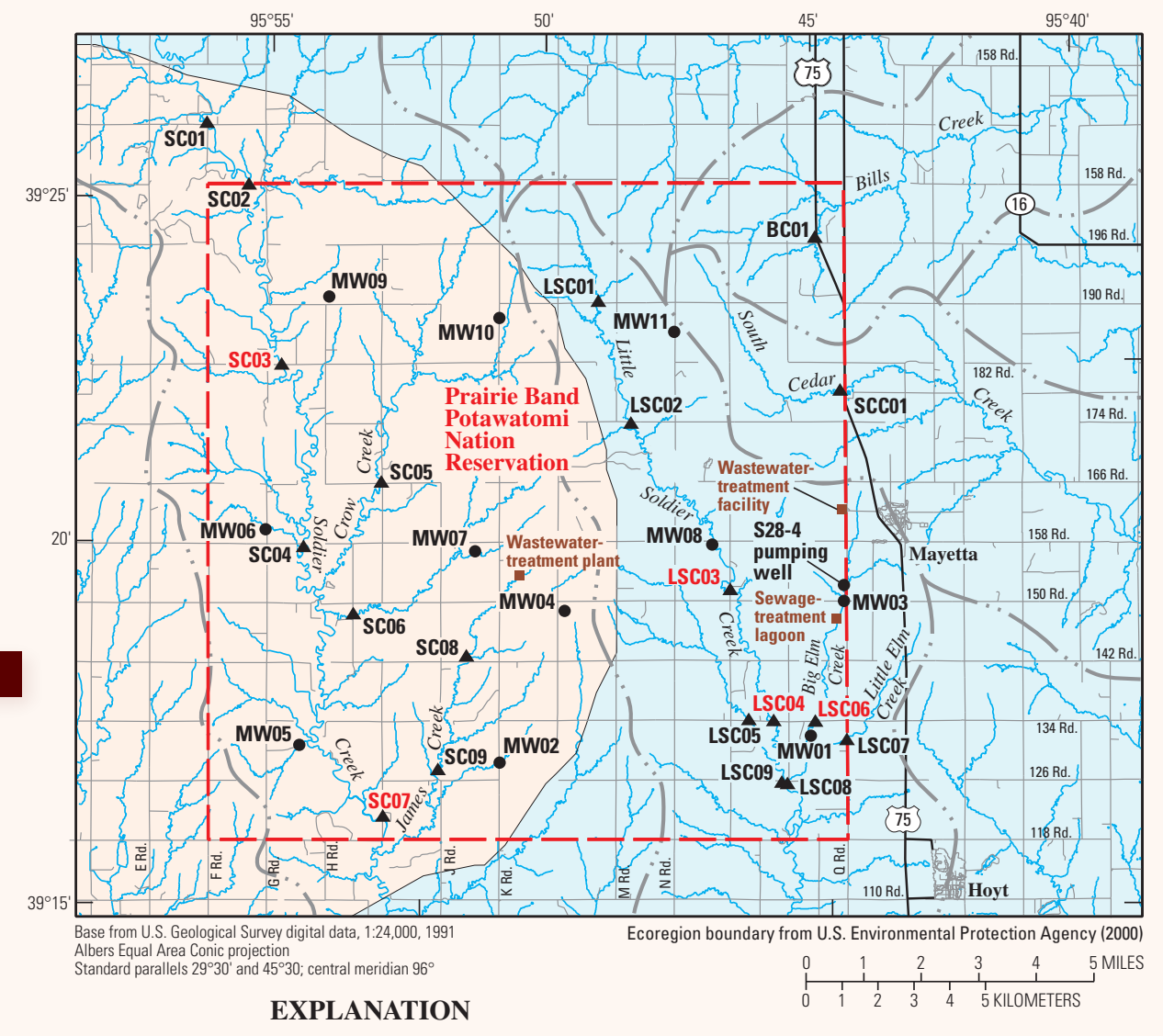

Ecoregions

IV, Great Plains Grass and Shrublands

VI, Corn Belt and Northern Great Plains Boundary of ecoregion

— " - Boundary of drainage basin

— B Boundary of reservation

$\mathrm{LSCO}_{\triangle}$ U.S. Geological Survey stream-water-quality monitoring site and identifier-Red identifier indicates quarterly samples collected at site

MW02 U.S. Geological Survey ground-water-quality monitoring site and identifier

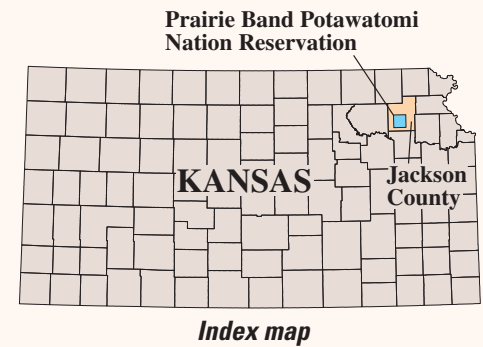

Index map

Figure 1. Location of water-quality monitoring sites on and near Prairie Band Potawatomi Reservation, northeastern Kansas. 
- Nitrate exceeded USEPA recommended criterion for aggregate nutrient ecoregion VI in surface-water samples. Nitrite plus nitrate (sometimes referred to as "nitrate") concentrations exceeded nutrient ecoregion criterion $(0.633 \mathrm{mg} / \mathrm{L})$ in 20 percent of surface-water samples. Total nitrogen concentrations also exceeded the recommended criterion $(1.22 \mathrm{mg} / \mathrm{L})$ in 25 percent of surface-water samples. Ecoregion criteria are from USEPA (2000).

- Large concentrations of nitrite plus nitrate were detected in one monitoring well. All five water samples analyzed from well MW11 had concentrations of nitrite plus nitrate exceeding the Maximum Contaminant Level (MCL) of 10 mg/L (U.S. Environmental Protection Agency, 2006). Agricultural activities in the area and the proximity of the well to an open hand-dug well may contribute to these relatively large nitrite plus nitrate concentrations.

- Total phosphorus concentrations frequently exceeded the aquatic-life goal in surface-water samples. Some surface-water samples from every site exceeded the USEPA recommended goal of $0.10 \mathrm{mg} / \mathrm{L}$ established to limit cultural eutrophication (nutrient enrichment) of flowing water (U.S. Environmental Protection Agency, 1986).

\section{Trace Elements}

- Arsenic, boron, and iron exceeded their respective waterquality criteria in ground-water samples from some wells. Trace elements were found in small concentrations in ground-water samples, with a few wells exceeding USEPA drinking-water-quality criteria (U.S. Environmental Protection Agency, 2006). Arsenic was detected in water from well MW06 at concentrations two to three times larger than the MCL of $10 \mu \mathrm{g} / \mathrm{L}$ (micrograms per liter). Boron exceeded the DWA of $600 \mu \mathrm{g} / \mathrm{L}$ in water from well MW03, and iron consistently exceeded the SDWR of $300 \mu \mathrm{g} / \mathrm{L}$ in water from wells MW01, MW03, and MW06. The implication of these large concentrations of trace elements is that before ground water from some areas on the reservation can be used as a drinking-water supply, treatment may be needed to remove excessive amounts of some trace elements. Trace elements did not exceed USEPA water-quality criteria in surface-water samples.

\section{Pesticides and Organic Compounds}

- Pesticides were detected frequently in surface-water samples, occasionally exceeding water-quality criteria. Surface-water samples were analyzed using the ELISA (enzyme-linked immunosorbent assay) triazine herbicide screen. Five quarterly sampled monitoring sites had some detection of pesticides in 58 percent of samples; however, only one of these samples exceeded the USEPA MCL for atrazine of $3.0 \mu \mathrm{g} / \mathrm{L}$ as an annual average (U.S. Environmental Protection Agency, 2006).

- Pesticides were not detected frequently in ground-water samples. Alachlor, atrazine, cyanazine, and simazine were detected occasionally in water from some wells at small concentrations (less than $0.1 \mu \mathrm{g} / \mathrm{L}$ ).
- Fecal bacteria are common in surface water on the reservation. For example, Escherichia coli (E. coli) were routinely detected in surface-water samples from every site, at times in densities greater than the single-sample maximum of 9,760 col/100 mL (colonies per 100 milliliters of water) set by the Kansas Department of Health and Environment (2004) for secondary contact recreation such as wading, fishing, trapping, and hunting. Fecal bacteria densities tended to be largest during the spring and summer months (May and June) when streamflows were largest.

- Fecal bacteria occasionally were detected in ground-water samples in low densities. Ground-water samples from the reservation generally showed little to no fecal contamination. Enterococci were most frequently detected, with some number of colonies in 57 percent of samples collected.

\section{References}

Kansas Department of Health and Environment, 2004, Kansas surface water quality standards: Information available on Web, accessed February 6, 2007, at http://www.kdheks.gov/water/ download/swqs_numeric_criteria.pdf

Schmidt, H.C. Ross, 2004, Quality of water on the Prairie Band Potawatomi Reservation, northeastern Kansas, May 2001 through August 2003: U.S. Geological Survey Scientific Investigations Report 2004-5243, 69 p.

Schmidt, H.C. Ross, Mehl, H.E., and Pope, L.M., 2007, Water quality on the Prairie Band Potawatomi Reservation, northeastern Kansas, June 1996 through August 2006: U.S. Geological Survey Scientific Investigations Report 2007-5201, 75 p.

Trombley, T.J., 1999, Surface-water quality on the Prairie Band of Potawatomi Reservation, northeastern Kansas, June 1996 through November 1998: U.S. Geological Survey WaterResources Investigations Report 99-4266, 67 p.

Trombley, T.J., 2001, Quality of water on the Prairie Band Potawatomi Reservation, northeastern Kansas, February 1999 through February 2001: U.S. Geological Survey WaterResources Investigations Report 01-4196, 51 p.

U.S. Environmental Protection Agency, 1986, Quality criteria for water, 1986: U.S. Environmental Agency Report 440/5-86001, unnumbered pages.

U.S. Environmental Protection Agency, 2000, Ambient water quality criteria recommendations_-information supporting the development of State and tribal nutrient criteria, rivers and streams in nutrient ecoregion VI: Washington D.C., EPA 822-B-00-017, December 2000, information available on Web, accessed May 2004 at http://www.epa.gov/watersciencel criteria/nutrient/ecoregions/rivers/rivers_6.pdf

U.S. Environmental Protection Agency, 2006, 2006 Edition of the drinking water standards and health advisories: Washington, D.C., EPA 822-R-06-013, summer 2006, information available on Web, accessed February 13, 2007, at http://www.epa. gov/waterscience/criteria/drinking/dwstandards.pdf

\section{For additional information visit the USGS Web site at: http://ks.water.usgs.gov or contact: \\ U.S. Geological Survey \\ Director, Kansas Water Science Center 4821 Quail Crest Place \\ Lawrence, Kansas 66049-3839 \\ (785) 842-9909 or E-mail: dc_ks.usgs.gov}

